І. Д. Спіріна, А. В. Шорніков, Р. М. Тимофєєв, Є. С. Феденко

ДЗ “Дніпропетровська медична академія МОЗ України”, м. Дніпро

\title{
ФОРМУВАННЯ КОМПЕТЕНТНОСТЕЙ У СТУДЕНТІВ-МЕДИКІВ 3 ДИСЦИПЛІНИ “ПСИХІАТРІЯ. НАРКОЛОГІЯ” ЗА ДОПОМОГОЮ РОЛЬОВИХ ІГОР
}

\author{
I. D. Spirina, A. V. Shornikov, R. M. Tymofieiev, E. S. Fedenko \\ Dnipropetrovsk Medical Academy of Health Ministry of Ukraine, Dnipro \\ FORMATION OF COMPETENCES IN MEDICAL STUDENTS ON THE \\ DISCIPLINE OF PSYCHIATRY. NARCOLOGY BY MEANS OF ROLE \\ GAMES
}

\begin{abstract}
Мета роботи - розробка та впровадження в практичну педагогічну діяльність рольових ігор з деяких тем дисципліни “Психіатрія. Наркологія”.

Основна частина. Сучасна медична освіта потребує від студентів не лише освоєння певних знань та вмінь, а формування необхідних компетентностей, тобто навичок використання отриманих знань у практичній діяльності. Однією з таких компетентностей $є$ здатність швидко та ефективно діагностувати невротичні розлади у хворих. Дослідження базувалось на оцінці ефективності використання авторських рольових ігор при вивченні теми “Невротичні розлади”. У дослідженні взяли участь 44 студенти IV курсу медичних факультетів спеціальності “Лікувальна справа”. Для оцінки ефективності рольових ігор використано опитувальник, який включав 4 питання про доцільність, ефективність та особисті враження студентів від запропонованої форми навчання. Отримані результати виявили високу ефективність та позитивне ставлення студентів до даного методу.

Висновки. За результатами проведеного дослідження зроблено висновок про можливість та доцільність використання рольових ігор у навчанні студентів дисципліни “Психіатрія. Наркологія”, оскільки виступаючи або у ролі хворого, або у ролі лікаря студенти краще та глибше структурують отримання знання та можуть у безпечних умовах тренуватися використовувати їх на практиці. Запропонована форма заняття здатна поліпшити рівень навчання студентів та формувати заплановані типовою навчальною програмою компетенції з дисципліни “Психіатрія. Наркологія”.
\end{abstract}

Ключові слова: рольова гра; студенти; психіатрія; наркологія; інноваційні методи навчання.

The aim of the work - to develop and introduce into practice of pedagogical activities the role games on some topics of the discipline of Psychiatry. Narcology.

The main body. Modern medical education requires from students not only receiving a certain list of knowledge and skills, but also the formation of the necessary competences, that is, the skills of using the acquired knowledge in practice. One such competency is the ability to quickly and effectively diagnose neurotic disorders in patients. The research was based on the effectiveness of the use of author's role-playing games in the study of the topic "Neurotic disorders". The study was attended by 44 students of the $4^{\text {th }}$ course of Medical Faculty on the specialty of Medicine. For assess effectiveness of role games, a questionnaire was used that included 4 questions about the expediency, effectiveness and personal impressions of students on the proposed form of study. The obtained results revealed high efficiency and positive attitude of students to this method.

Conclusions. According to results of the study, authors made a thesis about possibility and expediency of using role-playing games in teaching students the discipline of Psychiatry. Narcology. Acting either "a patient" or as "a doctor", students better and deeper structure the acquisition of knowledge and can to train using them in practice in a safe environment. Proposed form of a lesson is able to improve students the educational level and form competencies that have planned in the typical curriculum of the discipline of Psychiatry. Narcology.

Key words: role game; students; psychiatry; narcology; innovative teaching methods.

Вступ. Компетентнісний підхід обумовлює інноваційні зміни у формуванні змісту професійної підготовки майбутніх медиків, визначення загальних та фахових компетентностей. Заплановані програмні результати навчання передбачають вироблення у студентів не тільки знань, вмінь і нави- чок, а саме компетентностей, на що і спрямована основна діяльність професорсько-викладацького складу. Останні роки вважається, що у навчанні клінічних дисциплін варто віддавати перевагу активним методам навчання, коли студент стає активним учасником навчального процесу. Існує багато 
методів активного навчання, за допомогою яких можливо сформувати відповідні компетентності, зокрема практичні заняття, вирішення клінічних задач, навчальні відеофільми, тренінги, майстеркласи, метод кейсів тощо. Одним із таких засобів $\epsilon$ використання клінічних рольових ігор (ділових ігор) [1]. Рольові ігри потребують мінімальної підготовки до їх проведення, дозволяють досягнути третього та четвертого рівнів навчання за В. П. Беспальком: здатності застосовувати знання на практиці та вміння перенести отримані раніше знання на вирішення нових завдань та проблем [2]. Серед іншого будь-які інноваційні методи навчання викликають живий інтерес у студентів. Рольові ігри допомагають студентам краще опановувати відповідні компетентності, оскільки під час ігор відсутній психологічний тиск відповідальності, властивий традиційним формам навчальної діяльності. Це дає змогу перетворювати загальні знання в особистісно значущі, проте вимагає від учасників систематизованих і глибоких знань для застосування їх у подальшій самостійній професійній діяльності [3]. Окрім цього, рольові ігри забезпечують більш якісне формування мотивації до опанування практичних навичок та професійних вмінь у студентів, формують клінічне мислення та дозволяють застосувати отримані вміння для вирішення конкретних завдань і покращення результатів своєї практичної роботи [4]. Наразі рольові, або ділові ігри широко використовуються у післядипломній підготовці як інтегральний метод контролю професійної підготовки лікарів-інтернів, тому що допомагають об’єктивно оцінити фахові компетентності в умовах реальної конкретної діяльності [5].

Мета роботи - оцінка ефективності використання рольових ігор для опановування студентами IV курсу відповідних компетенцій із дисципліни “Психіатрія. Наркологія” по темі “Невротичні розлади”.

Основна частина. У нашому дослідженні ми виходили з того, що майбутні лікарі повинні досягти саме 3 рівня знань, на формування якого і спрямований навчальний процес відповідно до чинних освітньо-кваліфікаційних характеристик та освітньо-професійних програм підготовки фахівців у галузі знань “Охорона здоров’я”.

Об’єктом дослідження були 44 студенти IV курсу медичного факультету. На практичному занятті з дисципліни “Психіатрія. Наркологія” під час розгляду теми “Невротичні розлади” оцінювання знань студентів проводилося за допомогою клініч- них рольових ігор. На початку заняття студентам роз'яснювалась суть методики. Потім студенти ділилися попарно відповідно до порядкових номерів у журналі відвідувань: перший за списком з другим, третій з четвертим тощо. Якщо кількість студентів була непарною, то останній студент виступав у ролі супервізора й оцінював інших студентів. Один студент із пари тягнув одну 3 двох карток, на зворотній стороні котрих було написано “лікар” або “хворий”. Витягнувши картку “лікар”, виконував у рольовій грі роль лікаря, інший студент грав хворого. Студент, який отримав роль “хворого”, обирав одну з-поміж багатьох карток, на зворотній стороні котрих були написані нозологічні форми невротичних розладів згідно з МKX-10. Обрану картку він показував лише викладачу. Надалі починалося опитування “хворого” “лікарем”. Студент, який отримував роль хворого, був зобов’язаний відповідати у межах нозології, яка йому дісталася, коли він витягав картку. Студент, який став “лікарем”, міг ставити будь-які запитання, знаючи, що у “хворого” одна з нозологій з групи невротичних розладів (таким чином він міг обирати лише питання, які дозволяють диференціювати між собою невротичні розлади, що дозволяє економити час на практичному занятті). “Лікар” міг задавати лише 10 запитань стосовно проявів симптомів у “хворого”. “Хворий” повинен відповідати у межах нозології, яка йому дісталась, відповідати лише про те, про що питали, не допомагаючи своїми відповідями “лікарю”. Після опитування “хворого” “лікар” повинен був відповісти на три запитання: який невротичний розлад демонстрував “пацієнт”, обгрунтувати діагноз та призначити лікування. Оцінювання проводили таким чином: студент, який грав хворого, оцінювався по тому, наскільки він обізнаний у симптомах того розладу, картку з яким він витягнув. Якщо він з 10 питань, які йому ставив “лікар”, правильно, згідно з нозологією, відповість на 9-10, він отримував “відмінно”, якщо відповість на 8 - це “добре”, 6-7 правильних відповідей - “задовільно”, в іншому випадку - “незадовільно”. “Лікар” оцінювався за 3 критеріями: правильність діагнозу, правильність в його обгрунтуванні та правильність лікування. Якщо діагноз встановлюється неправильно, студенту говорять правильний, і він повинен його обгрунтувати та призначити лікування. Якщо усі 3 критерії правильні, студент отримує оцінку “відмінно”, якщо 2 критерії правильні - “добре”, одна правильна відповідь - “задовільно”, в іншому випадку - “незадовільно”. Після кожної рольової 
гри проводилось обговорення випадку, надавалися відповіді на запитання студентів. Якщо у рольовій грі брав участь “супервізор” (студент, який залишився без пари), він повинен був оцінювати до викладача правильність відповідей “хворого” та “лікаря”, після чого він сам буде оцінений на знання теми. Зауважимо, що під час рольових ігор акторська майстерність не оцінювалась.

Для оцінки ефективності запропонованої методики усі студенти заповнювали анонімну анкету, яка включала такі питання:

1. Наскільки Вам сподобалась дана методика оцінювання знань?

2. В якій мірі рольова гра дозволяє поліпшити запам'ятовування навчального матеріалу по темі?

3. Наскільки точно рольова гра дозволяє оцінити рівень Ваших знань?

4. Чи Ви бажаєте, аби рольові ігри проводились на практичних заняттях 3 інших тем?

Перші 3 пункти оцінювалися від 1 бала (зовсім не сподобалась, не дозволяє оцінити знання, зовсім не покращують запам'ятовувати матеріал) до 10 балів (максимально сподобалась, максимально дозволяє оцінити). Останній пункт - оцінювався “так” чи “ні”.

В анонімному опитуванні взяли участь 44 студенти. По першому пункту опитувальника (сподобалось) середній бал - 8,6, по другому пункту (поліпшення запам’ ятовування) середній бал - 7,8, мода - 8. По третьому пункту опитувальника (оцін-

\section{Список літератури}

1. Сабатовська I. С. Педагогічні умови використання активних методів навчання у процесі підготовки фахівців медичного профілю / І. С. Сабатовська, М. А. Селезньов // Медична освіта. - 2017. - № 4. - С. 48-52.

2. Використання “рівнів навчання” для оцінки знань студентів на циклі “Психіатрія. Наркологія” / І. Д. Спіріна, С. В. Рокутов, Р. М. Тимофєєв, А. В. Шорніков // Медична освіта. - 2016. - № 3. - С. 90-92.

3. Олійник Н. Ю. Ефективність ігрових моделей навчання в системі сучасної вищої освіти / Н. Ю. Олійник // Наукові записки. Серія: Проблеми методики фізикоматематичної і технологічної освіти. - 2016. - Т. 2, № 7. - С. 70-75.

\section{References}

1. Sabatovska, I.S., \& Selezniov, M.A. (2017). Pedahohichni umovy vykorystannia aktyvnykh metodiv navchannia u protsesi pidhotovky fakhivtsiv medychnoho profiliu [Pedagogical conditions of use active learning methods in the training of professional medical profile]. Medychna ка знань) середній бал - 8,1, мода 7,5. По четвертому пункту анкети (хотіли б повторити) - 93,2 \% (41 3 44) студентів відповіли “так”. Переважна більшість студентів дуже позитивно оцінила застосування рольових ігор на практичному занятті та хотіли б у подальшому застосовувати даний метод для оцінки їх знань на практичних заняттях. Рольові ігри дозволяють досягнути 3 рівня знань за В. П. Беспальком та застосовувати свої знання на практиці. Отримані результати свідчать, що студентам більше подобаються рольові ігри, ніж вирішення клінічних задач або кросвордів, які також дозволяють досягнути відповідного рівня знань $[2,6]$. Більшість студентів вважає оцінку, яку вони отримали на практичному занятті за допомогою клінічних рольових ігор, справедливою, про що свідчить середня оцінка у 8,1 бала.

Висновки. Клінічні рольові ігри дозволяють формувати компетентності з дисципліни “Психіатрія. Наркологія” в повному обсязі, позитивно оцінюються студентами, дозволяють досягати 3 рівня знань, не приводять до змін у навчальних планах, та потребують мінімальної підготовки до їх проведення, а також дозволяють досить об’ єктивно оцінити застосування знань студентів у практичній діяльності. Враховуючи все вищенаведене, клінічні рольові ігри можуть бути рекомендовані як альтернатива деяким традиційним методам оцінювання (наприклад тестам) або як доповнення до традиційних методів навчання та оцінювання.

4. Роль рольових ігор у вивченні акушерства та гінекології / А. М. Громова, Н. І. Мітюніна, В. Б. Мартиненко [та ін.] // Медична освіта. - 2017. - № 2. С. 117-120.

5. Використання сучасних інноваційних технологій у процесі професійної підготовки лікарів-інтернів / Д. П. Мирний, А. І. Мирна, О. О. Савченко, Ю. В. Кацюба // Збірник наукових праць співробітників НМАПО ім. П. Л. Шупика. - 2015. - № 24 (1). - С. 639-645.

6. Наумов Л. Б. Учебные игры в медицине / Л. Б. Наумов. - Ташкент : Медицина, 1986. - С.17.

osvita - Medical Education, 23, (4), 48-52. doi: 10.11603/ me.2414-5998.2017.4.8286 [in Ukrainian].

2. Spirina, I.D., Rokutov, S.V., Tymofieiev, R.M., \& Shornikov, A.V. (2016). Vykorystannia "rivniv navchannia" dlia otsinky znan studentiv na tsykli "Psykhiatriia. Narkolo- 
hiia” [Using "level of training” for the student knowledge evaluation on the cycle "Psychiatry. Narcology"]. Medychna osvita - Medical Education, 22 (3), 90-92. doi:10.11603/ me.2414-5998.2016.3.6920 [in Ukrainian].

3. Oliinyk, N.Yu. (2016). Efektyvnist ihrovykh modelei navchannia v systemi suchasnoi vyshchoi osvity [The efficiency of gaming models of teaching in the system modern higher education]. Naukovi zapysky. Seriia: Problemy metodyky fizyko-matematychnoi i tekhnolohichnoi osvity - Scientific Notes. Series: Problems of Methodology of PhysicalMathematical and Technological Education, 2 (7), 70-75 [in Ukrainian].

4. Hromova, A.M., Mitiunina, N.I., Martynenko, V.B., Nesterenko, L.A., \& Liakhovska, T.Yu. (2017). Rol rolovykh ihor u vyvchenni akusherstva ta hinekolohii [The role of role-playing games in the study of obstetrics and gynecology]. Medychna osvita - Medical Education, 23, (2), 117120. https://doi.org/10.11603/me.2414-5998.2017.2.7880 [in Ukrainian].

5. Myrnyi, D.P., Myrna, A.I., Savchenko, O.O., \& Katsiuba, Yu.V. (2015). Vykorystannia suchasnykh innovatsiinykh tekhnolohii u protsesi profesiinoi pidhotovky likariv-interniv [Applying modern innovative technologies for professional training of internship doctors]. Zbirnyk Naukovykh Prats Spivrobitnykiv NMAPO im. P.L. Shupyka - Collection of Scientific Works of Employees of P.L. Shupyk NMAPE, (24(1)), 639-645 [in Ukrainian].

6. Naumov, L.B. (1986). Uchebnye igry $v$ meditsyne [Educational games in medicine]. Tashkent: Meditsina [in Russian]. 